\title{
Acoustic Radiation Force Impulse (ARFI) elastography imaging of equine distal forelimb flexor structures
}

[Elastografia Acoustic Radiation Force Impulse (ARFI) das estruturas flexoras da porção distal do membro torácico de equinos]

\author{
N.S. Bernardi ${ }^{1}$, M.A.R. Feliciano ${ }^{2,4^{*}}$, K. Gravena ${ }^{1}$, M.L. Avante ${ }^{1}$, A.P.R. Simões ${ }^{1}$, \\ R.A.R. Uscategui ${ }^{3}$, D.P.M. Dias ${ }^{1}$, J.C. Lacerda Neto ${ }^{2}$
}

${ }^{1}$ Aluno de pós-graduação - Faculdade de Ciências Agrárias e Veterinárias - Universidade Estadual Paulista - Jaboticabal, SP

${ }^{2}$ Faculdade de Ciências Agrárias e Veterinárias - Universidade Estadual Paulista - Jaboticabal, SP

${ }^{3}$ Instituto de Ciências Agrícolas - Universidade Federal dos Vales do Jequitinhonha e Mucuri - Unaí, MG

${ }^{4}$ Universidade Federal de Santa Maria - Santa Maria, RS

\begin{abstract}
This study set out to determine normal values for acoustic radiation force impulse (ARFI) elastography of the superficial digital flexor tendon, deep digital flexor tendon, accessory ligament of the deep digital flexor tendon and suspensory ligament in horses. Twenty-four horses were submitted to conventional sonographic assessment and elastography imaging (quantitative ARFI method) of distal forelimb tendons and ligaments at nine anatomical regions. Elastograms depicted tendons and ligaments in orange to red tones consistent with greater stiffness. Shear wave velocity was higher in the longitudinal compared to the cross-sectional plane but did not differ significantly between the left and right forelimbs. The suspensory ligament was stiffer compared to remaining structures in the cross-sectional plane. Ligaments were stiffer than tendons and the deep digital flexor tendon was stiffer than the superficial digital flexor tendon in the longitudinal plane. Target structures were stiffer in male compared to female horses and stiffness tended to increase with age. ARFI elastography proved to be a feasible and reproducible imaging modality for assessment of distal forelimb tendons and ligaments in horses. Qualitative features derived from stiffness quantification in these structures can be applied to horses with musculoskeletal disorders, as well as to other animal species.
\end{abstract}

Keywords: equine, ultrasonography, locomotor system

\section{RESUMO}

Este trabalho objetivou estabelecer valores de referência por meio da elastografia ARFI ("Acoustic Radiation Force Impulse”) do tendão flexor digital superficial, tendão flexor digital profundo, ligamento acessório inferior e ligamento suspensor do boleto em equinos hígidos. Vinte e quatro equinos foram submetidos aos exames ultrassonográfico e elastográfico (método ARFI quantitativo) dos tendões e ligamentos da porção distal do membro torácico, em nove regiões anatômicas diferentes. Os elastogramas mostraram tendões e ligamentos de coloração alaranjada a vermelha, que representam maior rigidez. Não houve diferenças em relação ao membro avaliado; as velocidades de cisalhamento foram maiores nos planos longitudinais. No plano transversal, os ligamentos suspensores foram mais rígidos em comparação aos demais. No plano longitudinal, os ligamentos mostraram-se mais rígidos que os tendões, e o tendão flexor digital profundo, mais rígido que o tendão flexor digital superficial. As estruturas mostraram-se mais rígidas nos machos, e houve uma tendência à maior rigidez em animais mais velhos. A elastografia ARFI comprovou ser um método viável e reprodutível para avaliação dos tendões e ligamentos dos membros torácicos de equinos. As características qualitativas obtidas a partir

Recebido em 5 de março de 2019

Aceito em 17 de dezembro de 2019

*Autor para correspondência (corresponding author)

E-mail: marcusfeliciano@yahoo.com.br 
da rigidez dessas estruturas podem ser utilizadas para testes em equinos com distúrbios musculoesqueléticos e também em outras espécies animais.

Palavras-chave: equino, ultrassonografia, sistema locomotor

\section{INTRODUCTION}

Ultrasonography (US) is routinely used for visual assessment of tendons and ligaments in horses and is a valuable tool in clinical lameness evaluation. However, critical appraisal of image quality and proper image acquisition and interpretation are required for accurate diagnosis (Whitcomb, 2014). Also, this imaging modality is prone to artifacts such as acoustic shadowing at tendon margins. Hence, the ability of the US to detect early disintegration of tendon fibers and monitor lesion progression and therapeutic response is limited (Van Schie et al., 2013).

Elastography is a novel US technique aimed at early detection of tendon and ligament injuries (Dudea et al., 2011; Whitcomb, 2014). Soft tissue stiffness may be determined using different methods, such as compression elastography, acoustic radiation force impulse (ARFI) and real-time shear wave elastography (Dudea et al., 2011). ARFI is thought to be a safe, non-invasive elastography method for qualitative and quantitative assessment of soft tissue elasticity. Elastograms and shear wave velocity data (SWV) are generated by measuring the velocity with which sound waves return from tissue surfaces - lower in soft and higher in hard tissues respectively (Ruan et al., 2015). ARFI has been associated with lower inter-rater variability and higher repeatability and feasibility of compared to other elastography techniques (Goddi et al., 2012), given it does not entail external manual compression. In Veterinary Medicine, ARFI has been used for liver, kidney and spleen assessment in dogs (Holdsworth et al., 2014) and spleen assessment in cats (Feliciano et al., 2014a). The value of ARFI for diagnosis of mammary neoplasms (Feliciano et al., 2014b) and testicular disorders (Feliciano et $a l ., 2016)$ in dogs has also been reported.

Evidence suggests that elastography can be used to investigate mechanical properties of musculoskeletal tissues and may contribute to early diagnosis of tendon lesions and monitoring of tendon healing over the course of therapy (Drakonaki et al., 2012). In studies investigating common heel tendon stiffness in humans, ARFI elastography was able to provide reproducible quantitative real-time data and was thought to be an excellent ancillary imaging modality to Bmode US (Ruan et al., 2015). The applicability of compression elastography for evaluation of healthy tendons and ligaments and determination of tendon lesion chronicity and severity has been demonstrated in recent studies in horses (Lustgarten et al., 2014; Lustgarten et al., 2015). Monitoring of superficial digital flexor tendon (SFDT) healing after traumatic injuries has also been reported (Tamura et al., 2017). However, compressive elastography is highly operatordependent and therefore more prone to diagnostic error (Carvalho et al., 2015). Acoustoelastography has also been used to measure stiffness gradients in the SDFT in sound horses and is thought to be an accurate and repeatable imaging modality. Still, given that this technique is based on echo intensity changes (numerical grayscale brightness) reflecting tendon tissue strain rates from an unloaded to a loaded state (Ellison et al., 2014), image postprocessing and lack of movement during image acquisition are required.

ARFI elastography imaging of equine tendons and ligaments has not been reported to date. This study set out to investigate the value of ARFI elastography in determining the stiffness of normal soft tissue structures of the palmar aspect of the equine distal forelimb. Qualitative and quantitative features and normal ARFI values for the superficial digital flexor tendon (SDFT), deep digital flexor tendon (DDFT), accessory ligament of the deep digital flexor tendon (AL) and suspensory ligament (SL) have been described.

\section{MATERIALS AND METHODS}

Experimental procedures in this study were approved and supervised by the institutional committee on animal research and ethics (Protocol No. 15.069/16).

The sample comprised 24 sound adult horses (14 females and 10 males) of different breeds, as 
follows: Brazilian Sport Horse (Brasileiro de Hipismo), $\mathrm{n}=3$; Purebred/Crossbred Arabian, $\mathrm{n}=15$; mixed-breed, $\mathrm{n}=6$. Horses were aged $14 \pm 4$ years and weighed $439 \pm 55 \mathrm{~kg}$. Horses were submitted to physical and lameness examination with particular emphasis on the distal forelimbs. Conventional sonographic (US) assessment of flexor tendons and ligaments was carried out to rule out potential abnormalities. Sonographic assessments were performed by a trained veterinary ultrasound specialist (MARF; 15 years of experience) in a single session, at the same time of day and place.

Horses were sedated with intravenous detomidine hydrochloride $(0.01 \mathrm{mg} / \mathrm{kg})$ (DormiunV $^{\circledR}$; Agener União; São Paulo, Brazil) prior to US and elastographic assessments. The palmar surface of the distal forelimbs was clipped, and a coupling gel was applied to the skin for increased contact with the transducer and improved image quality; standoff pads were not used. Horses were scanned in the weightbearing position. Images of the left and right forelimb SDFT, DDFT, AL and SL were acquired using B-mode US and a linear array multi-frequency transducer set at $9.0 \mathrm{MHz}$ (ACUSON S2000®, Siemens, Munich). Crosssectional and longitudinal images were acquired at six $(1 \mathrm{~A}, 1 \mathrm{~B}, 2 \mathrm{~A}, 2 \mathrm{~B}, 3 \mathrm{~A}$ and $3 \mathrm{~B})$ and three (proximal, middle and distal) zones respectively. The SDFT and DDFT were scanned at all zones in both planes. The AL and SL were scanned at zones $1 \mathrm{~A}$ to $2 \mathrm{~B}$ and proximal to middle (crosssectional and longitudinal plane respectively). Regions of interest (ROIs) measuring $25 \mathrm{~mm}^{2}$ were randomly selected at three different sites per zone, so as to include the largest possible area of each target structure. Mean SWV $(\mathrm{m} / \mathrm{s})$ and depth of measurement at selected ROIs were automatically calculated using the ARFI software.

Tendon tissue echogenicity and fiber parallelism were assessed using conventional US.
Qualitative and quantitative analyzes were conducted using virtual touch tissue imaging quantification (VTIQ® Siemens, Munich) as per Tang et al. (2015). Qualitative ARFI assessment yielded a color scale image (elastogram) depicting tissue strain characteristics (deformable or non-deformable) in a range of shades, where bluish tones correspond to highly elastic (softer) tissues with lower SWV and reddish tones to less elastic (stiffer) tissues with higher SWV. The reverse color scheme was used in this study compared to sonoelastography techniques described elsewhere (Lustgarten et al., 2014, 2015; Tamura et al., 2017).

Data were submitted to statistical analysis following investigation of intra-observational variability. Shear wave velocity vales recorded at each observation, zone and limb were compared using the Kruskal-Wallis; whenever significant differences were found, median was compared using the Dunn's post-hoc test. Confidence intervals for these variables were constructed with a confidence level of $95 \%$. Correlations between numerical variables (age and weight) and SWV were investigated using Pearson's correlation coefficient. The level of significance was set at $5 \% \quad(\mathrm{P} \leq 0.05)$. Variables were expressed as medians and interquartile ranges (IQR).

\section{RESULTS}

Imaging assessments using B-mode US and ARFI elastography were uneventful and allowed proper imaging of flexor structures of the distal forelimb. Qualitative elastography revealed essentially non-deformable tendons and ligaments depicted in orange to red tones. Adjacent soft tissues appeared in green to blue tones, suggesting lower stiffness compared to tendons. Cross-sectional and longitudinal Bmode US and ARFI images are displayed in Figure 1. 

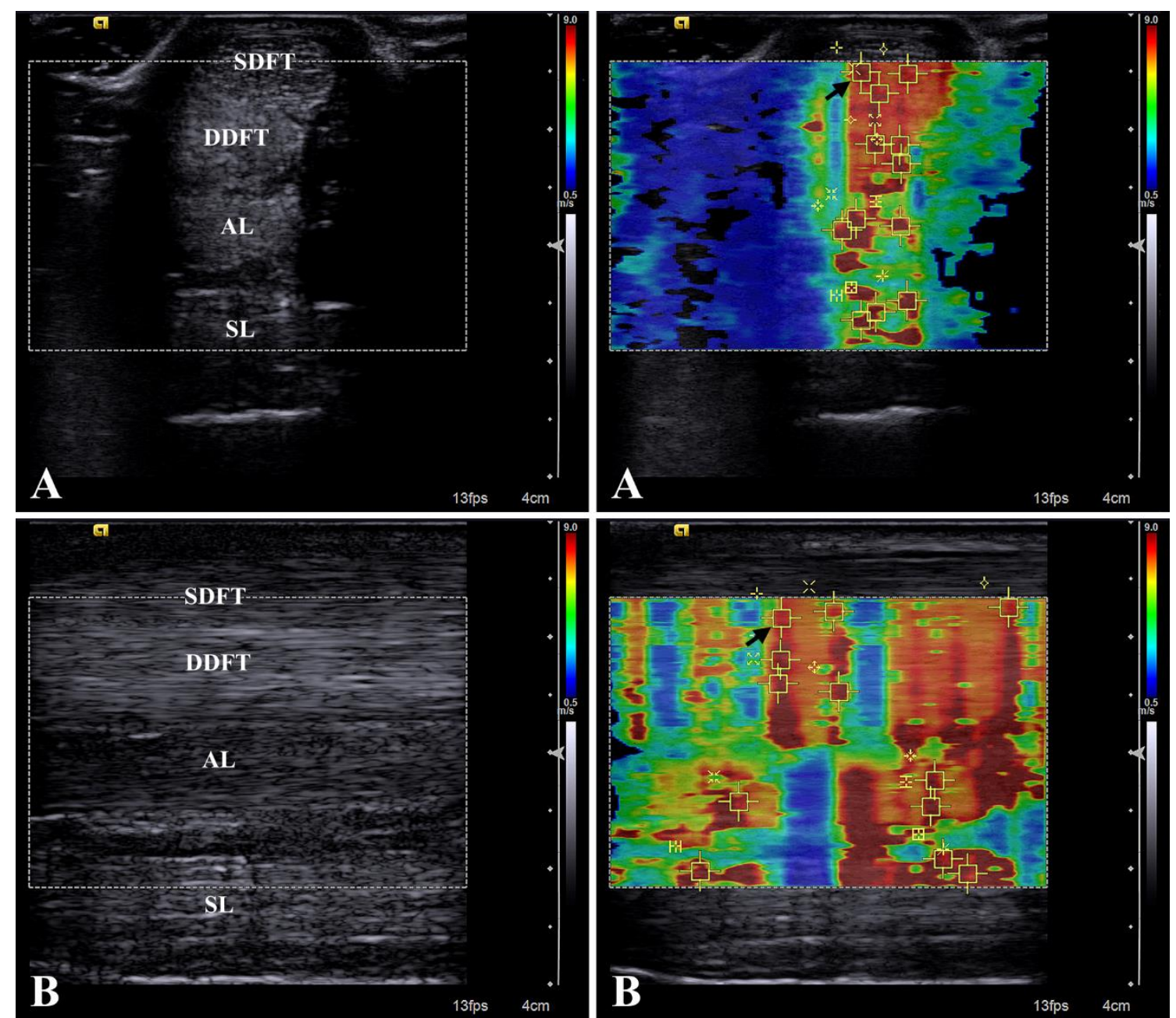

Figure 1. B-mode ultrasonography and corresponding acoustic radiation force impulse (ARFI) elastography image of the palmar aspect of the equine distal forelimb. (A) Cross-sectional image at zone 1A. (B) Longitudinal image at proximal zone. Note the superficial digital flexor tendon (SDFT), deep digital flexor tendon (DDFT), accessory ligament of the deep digital flexor tendon (AL) and suspensory ligament (SL). Yellow squares indicate regions of interest selected for automatic measurement of shear wave velocity at different depths in different structures.

Shear wave velocity $(\mathrm{P}=0.87)$ and depth of measurement $(\mathrm{P}=0.16)$ did not differ significantly between different ROIs within each structure/zone, ensuring data quality and accuracy.

Pooled median (IQR) SWV $(n=716)$ did not differ significantly $(8.0(0.7)$ and $7.8(0.6) \mathrm{m} / \mathrm{s}$, left and right forelimb respectively; $\mathrm{P}=0.142$ ). Shear wave velocity was significantly higher in longitudinal compared to cross-sectional images $(8.0 \pm 0.8 \mathrm{~m} / \mathrm{s}$ and $7.8 \pm 0.7 \mathrm{~m} / \mathrm{s}$ respectively;
$\mathrm{P} \leq 0.01)$. Shear wave velocity recorded in crosssectional images differed significantly $(\mathrm{P} \leq 0.01)$ between structures, the SL being the stiffest structure and the SDFT stiffer than the AL. Shear wave velocity recorded in longitudinal images also differed significantly $(\mathrm{P} \leq 0.01)$ between structures, ligaments being stiffer than tendons and the DDFT stiffer than the SDFT (Tab. 1). Median SWV recorded in cross-sectional SDFT, DDFT, AL and SL images did not differ significantly (Tab. 2). 
Table 1. Median (IQR), maximum (Max) and minimum (Min) values of shear wave velocity (m/s) measured in cross-sectional (SWVtrans) and longitudinal (SWVlong) images of the superficial digital flexor tendon (SDFT), deep digital flexor tendon (DDFT), accessory ligament of the deep digital flexor tendon (AL) and suspensory ligament (SL) acquired using ARFI elastography in sound horses $(n=24)$, and respective confidence intervals $(95 \% \mathrm{CI})$

\begin{tabular}{lllll}
\multicolumn{1}{c}{ Variable } & \multicolumn{1}{c}{ SDFT } & \multicolumn{1}{c}{ DDFT } & \multicolumn{1}{c}{ AL } & \multicolumn{1}{c}{ SL } \\
\hline SWVtrans & $7.8\left(0.5^{\mathrm{c}}\right)$ & $7.7\left(0.4^{\mathrm{bc}}\right)$ & $7.7\left(0.8^{\mathrm{b}}\right)$ & $8.1\left(0.8^{\mathrm{a}}\right)$ \\
SWVtrans Min-Max & $5.8-8.8$ & $5.7-8.8$ & $6-8.7$ & $5.3-9.6$ \\
SWVtrans 95\% CI & $7.8-7.9$ & $7.7-7.8$ & $7.6-7.8$ & $8-8.2$ \\
SWVlong & $7.8\left(0.5^{\mathrm{c}}\right)$ & $7.9\left(0.5^{\mathrm{b}}\right)$ & $8.2\left(0.63^{\mathrm{a}}\right)$ & $8.3\left(0.6^{\mathrm{a}}\right)$ \\
SWVlong Min-Max & $6.9-8.7$ & $7.1-8.6$ & $6.8-9.4$ & $6.7-9.7$ \\
SWVlong 95\% CI & $7.7-7.9$ & $7.9-8.0$ & $8.1-8.4$ & $8.2-8.5$ \\
\hline
\end{tabular}

Values followed by different lower-case letters in the same line differ significantly $(\mathrm{P} \leq 0.05)$.

Table 2. Median (IQR), maximum (Max) and minimal (Min) shear wave velocity (m/s) and depth (cm) of measurement values determined from cross-sectional images of the superficial digital flexor tendon (SDFT), deep digital flexor tendon (DDFT), accessory ligament of the deep digital flexor tendon (AL) and suspensory ligament (SL) acquired using ARFI elastography in sound horses $(n=24)$, and respective confidence intervals $(95 \% \mathrm{CI})$

\begin{tabular}{llllllll}
\hline & \multicolumn{1}{c}{$1^{\mathrm{a}}$} & \multicolumn{1}{c}{$1 \mathrm{~B}$} & \multicolumn{1}{c}{$2 \mathrm{~A}$} & \multicolumn{1}{c}{ 2B } & \multicolumn{1}{c}{$3 \mathrm{~A}$} & \multicolumn{1}{c}{$3 \mathrm{~B}$} \\
\hline \multirow{4}{*}{ SDFT } & Median (IQR) & $7.8(0.5)$ & $7.8(0.4)$ & $7.9(0.5)$ & $7.8(0.4)$ & $7.9(0.5)$ & $7.7(0.6)$ \\
& Min - Max & $5.8-8.5$ & $7.2-8.8$ & $7.3-8.7$ & $7.2-8.4$ & $6.5-8.5$ & $6.6-8.4$ \\
& 95\% CI & $7.7-8.0$ & $7.7-8.0$ & $7.6-7.9$ & $7.8-8.0$ & $7.6-8.1$ & - \\
& Depth & 0.63 & 0.61 & 0.54 & 0.51 & 0.43 & 0.40 \\
& Median (IQR) & $7.8(0.5)$ & $7.8(0.3)$ & $7.7(0.4)$ & $7.7(0.3)$ & $7.7(0.4)$ & $7.7(0.2)$ \\
DDFT & Min - Max & $5.7-8.5$ & $6.9-8.8$ & $6.9-8.8$ & $7.3-8.4$ & $7.3-8.3$ & $7.5-8.5$ \\
& 95\% CI & $7.7-8.0$ & $7.7-7.9$ & $7.7-8.1$ & $7.6-7.8$ & $7.7-7.9$ & $7.6-7.8$ \\
& Depth & 1.12 & 1.10 & 1.00 & 0.94 & 0.93 & 0.97 \\
& Median (IQR) & $7.8(0.8)$ & $7.8(0.8)$ & $7.6(0.6)$ & $7.7(0.6)$ & - & - \\
AL & Min - Max & $6.0-8.7$ & $6.2-8.7$ & $6.8-8.6$ & $6.7-8.7$ & - & - \\
& 95\% CI & $7.5-8.0$ & $7.5-8.1$ & $7.5-7.8$ & $7.5-7.9$ & - & - \\
& Depth & 2.03 & 1.94 & 1.77 & 1.65 & - & - \\
& Median (IQR) & $8.0(1)$ & $8.1(0.7)$ & $8.1(0.9)$ & $8(0.7)$ & - & - \\
& Min - Max & $5.3-8.8$ & $6.7-9.6$ & $6.3-8.8$ & $7.1-9.3$ & - & - \\
& 95\% CI & $7.7-8.2$ & $7.8-8.3$ & $7.9-8.3$ & $7.9-8.3$ & - & - \\
& Depth & 2.80 & 2.74 & 2.67 & 2.63 & - & - \\
\hline
\end{tabular}

1A, 1B, 2A, 2B, 3A, 3B: cross-sectional imaging zones

The SDFT appeared harder in the proximal compared to the distal zone in longitudinal images. In the DDFT, SWV decreased from the proximal to the middle and distal zones, with lowest SWV values recorded distally (Tab. 3).

Shear wave velocity was significantly higher $(\mathrm{P}=0.0047)$ in male compared to female horses. Horses in this sample were defined as older or adults (over and under 15 years of age respectively). Horse age was weakly correlated with SWV $(\mathrm{P} \leq 0.01, \mathrm{r}=0.16)$, older horses having significantly higher tendon and ligament SWV values compared to adult horses $(8.0 \pm 0.6$ and $7.7 \pm 0.6$ respectively; $\mathrm{P} \leq 0.01)$. Body weight was not correlated with SWV in this study $(\mathrm{P}=0.39$, $\mathrm{r}^{=}-0.02$ ).

\section{DISCUSSION}

Findings of this study suggest ARFI elastography can be used for imaging assessment of distal forelimb tendons and ligaments in horses. This imaging modality proved to be user-friendly and allowed qualitative and quantitative characterization of soft tissue elasticity. Lack of intra-observational variability supports the repeatability of the technique. ARFI does not entail manual compression and is operatorindependent in nature. 
Table 3. Median (IQR), maximum (Max) and minimal (Min) shear wave velocity $(\mathrm{m} / \mathrm{s})$ and depth (cm) of measurement values determined from longitudinal images of the superficial digital flexor tendon (SDFT), deep digital flexor tendon (DDFT), accessory ligament of the deep digital flexor tendon (AL) and suspensory ligament (SL) using ARFI elastography in sound horses $(n=24)$, and respective confidence intervals $(95 \% \mathrm{CI})$

\begin{tabular}{|c|c|c|c|c|}
\hline & & Proximal & Middle & Distal \\
\hline \multirow{4}{*}{ SDFT } & Median (IQR) & $7.9\left(0.5^{\mathrm{a}}\right)$ & $7.8\left(0.4^{\mathrm{ab}}\right)$ & $7.7\left(0.5^{\mathrm{a}}\right)$ \\
\hline & Min - Max & $7.2-8.7$ & $7.2-8.7$ & $6.9-8.3$ \\
\hline & $95 \% \mathrm{CI}$ & $7.8-8.1$ & $7.6-7.9$ & $7.5-7.9$ \\
\hline & Depth & 0.65 & 0.59 & 0.47 \\
\hline \multirow{4}{*}{ DDFT } & Median (IQR) & $8.0\left(0.4^{\mathrm{a}}\right)$ & $7.9\left(0.6^{b}\right)$ & $7.8\left(0.3^{\mathrm{c}}\right)$ \\
\hline & Min - Max & $7.6-8.6$ & $7.3-8.6$ & $7.1-8.5$ \\
\hline & $95 \% \mathrm{CI}$ & $7.9-8.2$ & $7.7-8.1$ & $7.7-7.9$ \\
\hline & Depth & 1.14 & 1.06 & 1.07 \\
\hline \multirow{4}{*}{$\mathrm{AL}$} & Median (IQR) & $8.2(0.7)$ & $8.2(0.6)$ & - \\
\hline & Min - Max & $7.1-9.4$ & $6.8-9.2$ & - \\
\hline & $95 \% \mathrm{CI}$ & $8.0-8.4$ & $8.1-8.4$ & - \\
\hline & Depth & 1.98 & 1.76 & - \\
\hline \multirow{4}{*}{ SL } & Median (IQR) & $8.5(0.7)$ & $8.3(0.5)$ & - \\
\hline & Min - Max & $6.7-9.3$ & $6.9-9.7$ & - \\
\hline & $95 \%$ CI & $8.3-8.6$ & $8.1-8.4$ & - \\
\hline & Depth & 2.76 & 2.70 & - \\
\hline
\end{tabular}

Values followed by different lower-case letters in the same line differ significantly $(\mathrm{P} \leq 0.05)$.

Therefore, it is thought to be more objective and accurate than acoustoelastography (Ellison et al., 2014) and compression elastography (Lustgarten et al., 2014). Future research is warranted to determine the sensitivity and specificity of the technique for tendon and ligament lesion diagnosis and follow-up. Technical difficulties and acoustic artifacts associated with sonographic image acquisition with limbs held in the non-weight-bearing position have been reported in horses (Lustgarten et al., 2014, 2015). Horses in this sample were scanned in full weight-bearing for increased measurement accuracy.

ARFI elastography data in this study revealed that tendons and ligaments are stiff, nondeformable structures, whereas adjacent tissues are elastic. Similar findings have been reported in compression elastography studies (Lustgarten et al., 2014). Lack of differences between left and right forelimbs in this trial are in keeping with acoustoelastographic imaging data (Ellison et al., 2014).

Different from compression elastography studies (Lustgarten et al., 2014), the SDFT, DDFT, AL and SL appeared stiffer (higher SWV) in the longitudinal compared to the cross-sectional plane in this sample. These differences may be attributed to the subjective nature compression elastography, methodological differences between studies (different ROIs) and anisotropic characteristics of tendon and ligament fibers. The latter hypothesis is based on Young's modulus theory stating that fiber orientation is an important factor in tissue tension determination (Miles, 1996) and is supported by the lower elasticity of the SFDT and DDFT in the longitudinal compared to the cross-sectional plane in this study.

Longitudinal image analysis revealed stiffness differences between zones, the SDFT and DDFT being stiffer proximally than distally. Previous studies failed to reveal tendon stiffness differences between longitudinal sections (Ellison et al., 2014; Lustgarten et al., 2014), except for one relative echogenicity study reporting higher SDFT echogenicity proximally than distally (Agut et al., 2009). Normal tendon echogenicity is primarily a function of collagen density and brightness of specular reflections at fiber interfaces (Van Schie et al., 2000). Elastic properties of a given tendon segment can be estimated from its echogenicity, which in turn is negatively correlated with stiffness (i.e., hyperechoic lesions are usually less stiff) 
(Crevier-Denoix et al., 2005; Lustgarten et al., 2015). Such assumptions are in keeping with findings of this study and further support the potential applicability of ARFI elastography for detection of subtle tendon and ligament lesions.

Ligaments were stiffer than tendons (higher SWV) in this study. The DDFT appeared stiffer than the SDFT and the SL was the stiffest of all structures evaluated. Unlike compressive techniques (Nightingale, 2011; Drakonaki et al., 2012), depth of measurement within operating ranges for ARFI elastography ensured reliable SWV determination and did not interfere with measurements, with no variability between selected ROIs. Therefore, findings of this study were thought to reflect morphofunctional differences between structures. Tendons and ligaments have related, albeit distinct mechanical functions (Dahlgren, 2007). Ligaments are subject to multi-axial loads whereas tendons are generally subject to uniaxial loads (Rumian et al., 2007). Ligaments are also thought to withstand higher tensile and compressive loads compared to tendons (Takahashi et al., 2014). As a result, tendons and ligaments have similar ultrastructural and histological appearance, but different organizational, structural, cellular, biochemical and molecular features. Tendon collagen fibers are arranged in a strictly parallel pattern, whereas ligament fibers are randomly arranged, have less mature crosslinks and are able to accommodate multi-axial loads. Ligaments also have a marginally smaller percentage of total collagen and a higher proportion of type III collagen and glycosaminoglycans (Dahlgren, 2007).

Shear wave velocity differed between male and female horses in this study. Morphofunctional and structural intergender differences in tendons and ligaments have not been reported in horses or humans to date (Agut et al., 2009; Ellison et al., 2014; Ruan et al., 2015). Further studies investigating intergender SWV differences are therefore warranted. Shear wave velocity was positively correlated with horse age in this study (i.e., soft tissue stiffness appeared to increase with age). Similar findings have been reported in ARFI elastography studies of the human Achilles tendon (Ruan et al., 2015). These changes are thought to reflect lower rates of collagen synthesis and increased cross-linking with ageing, leading to greater deposition of type III collagen in older horses (Birch et al., 1999).

Data from sonographic studies suggest the relative echogenicity of the SDFT, DDFT, AL and SL is higher in horses aged 2 to 16 years compared to horses aged 19 to 25 years (Agut et al., 2009). Given the athletic activity of horses in that study (Agut et al., 2009) was not described, it was not possible to determine whether the correlation between age and tendon and ligament stiffness was solely a function of age. Studies investigating the human Achilles tendon failed to reveal correlations between elastographic findings and age or gender (Drakonaki et al., 2009).

The diagnosis of desmo/tendinopathies in horses is typically based on clinical manifestations and ultrasonographic findings (Whitcomb, 2014). However, clinical signs and US lesions often resolve prior to tissue repair, as demonstrated by histological analysis. Therefore, clinical and US findings are not reliable parameters for lesion progression assessment (Marxen et al. 2004, Lacerda-Neto et al., 2013). Injured equine tendons appear soft and gelatinous on gross examination in response to inflammation (Lacerda-Neto et al., 2013). The fact that elastography reflects soft tissue stiffness and that correlations between tendon stiffness and soundness have been reported in humans suggest elastography may be a valuable ancillary imaging modality for diagnosis and follow-up of equine tendon and ligament injuries (Drakonaki et al., 2012).

This is the first study to describe the use ARFI elastography in horses. Findings of this study contribute relevant novel information regarding the stiffness of equine distal forelimb flexor tendons and ligaments. Quantitative assessment of soft tissue elasticity without tissue compression is thought to be a major advantage of ARFI. In this imaging modality, the mechanical impulse is triggered by the transducer (Wakker et al., 2018), minimizing intra- and inter-observational variability and yielding more objective, reliable and accurate data (Karatekin et al., 2018). Limitations of this study include small sample size and nonhomogeneous population regarding breed, age and athletic background. Reference ranges could not be determined in this study. Still ARFI 
elastography proved to be a user-friendly, noninvasive imaging modality for qualitative and quantitative assessment of soft tissue stiffness. Further studies with horses of different breeds, age and athletic background, with and without history of tendon and ligament injuries, are warranted. Findings of this study suggest ARFI elastography is a potentially valuable tool for more accurate diagnosis and follow-up of tendon and ligament injuries in horses.

\section{ACKNOWLEDGEMENTS}

Authors thank São Paulo Research Foundation for financial support (FAPESP protocol No. 2012/16635-2) and CNPq (National Council for Scientific and Technological Development) for the scholarship (process number 159988/20187). Authors also thank Jair Matos and Siemens Healthineers for technical support.

\section{REFERENCES}

AGUT, A.; MARTÍNEZ, M.L.; SÁNCHEZVALVERDE, M.A. et al. Ultrasonographic characteristics (cross-sectional area and relative echogenicity) of the digital flexor tendons and ligaments of the metacarpal region in Purebred Spanish horses. Vet. J., v.180, p.377-383, 2009.

BIRCH, H.L.; BAILEY, J.V.B.; BAILEY, A.J.; GOODSHIP, A.E. Age-related changes to the molecular and cellular components of equine flexor tendons. Equine Vet. J., v.31, p.391-396, 1999.

CARVALHO, F.; CINTRA, T.C.F.; CHAMMAS, M.C. Elastography: principles and considerations for clinical research in veterinary medicine. J. Vet. Med. Anim. Health, v.7, p.99110, 2015.

CREVIER-DENOIX, N.; RUEL, Y.; DARDILLAT, C. et al. Correlations between mean echogenicity and material properties of normal and diseased equine superficial digital flexor tendons: an in vitro segmental approach. $J$. Biomech., v.38, p.2212-2220, 2005.

DAHLGREN, L.A. Pathobiology of tendon and ligament injuries. Clin. Tech. Equine Pract., v.6, p.168-173, 2007.
DRAKONAKI, E.E.; ALLEN, G.M.; WILSON, D.J. Real-time elastography of the normal Achilles tendon: reproducibility and pattern description. Clin. Radiol., v.64, p.1196-1202, 2009.

DRAKONAKI, E.E.; ALLEN, G.M.; WILSON, D.J. Ultrasound elastography for musculoskeletal applications. Br. J. Radiol., v.85, p.1435-1445, 2012.

DUDEA, S.M.; GIURGIU, C.R.; DUMITRIU, D. et al. Value of ultrasound elastography in the diagnosis and management of prostate carcinoma. Med. Ultrasound, v.13, p.45-53, 2011.

ELLISON, M.E.; DUENWALD-KUEHL, S.; FORREST, L.J. et al. Reproducibility and feasibility of acoustoelastography in the superficial digital flexor tendons of clinically normal horses. Am. J. Vet. Res., v.75, p.581-587, 2014.

FELICIANO, M.A.R.; MARONEZI, M.C.; CRIVELLENTI, L.Z. et al. Acoustic radiation force impulse (ARFI) elastography of the spleen in healthy adult cats - a preliminary study. $J$. Small Anim. Pract., v.56, p.180-183, 2014a.

FELICIANO, M.A.R.; MARONEZI, M.C.; PAVAN, L. et al. ARFI elastography as complementary diagnostic method of mammary neoplasm in female dogs - preliminary results. $J$. Small Anim. Pract., v.55, p.504-508, 2014b.

FELICIANO, M.A.R.; MARONEZI, M.C.; SIMÕES, A.P.R. et al. Acoustic radiation force impulse (ARFI) elastography of testicular disorders in dogs: preliminary results. Arq. Bras. Med. Vet. Zootec., v.68, p.283-291, 2016.

GODDI, A.; BONARDI, M.; ALESSI, S. Breast elastography: a literature review. J. Ultrasound, v.15, p.192-198, 2012.

HOLDSWORTH, A.; BRADLEY, K.; BIRCH, S. et al. Elastography of the normal canine liver, spleen and kidneys. Vet. Radiol. Ultrasound, v.55, p.620-662, 2014.

KARATEKIN, Y.S.; KARAISMAILOGLU, B.; KAYNAK, G. et al. Does elasticity of Achilles tendon change after suture applications? Evaluation of repair area by acoustic radiation force impulse elastography. J. Orthop. Surg. Res., v.13. p.45, 2018. 
LACERDA-NETO， J.C.; FREITAS， J.M.R.; POGGIANI, F.M. et al. Serial superficial digital flexor tendon biopsies for diagnosing and monitoring collagenase-induced tendonitis in horses. Pesqui. Vet. Bras., v.33, p.710-718, 2013.

LUSTGARTEN, M.; REDDING, W.R.; LABENS, R. et al. Elastographic characteristics of the metacarpal tendon in horses without clinical evidence of tendon injury. Vet. Radiol. Ultrasound, v.55, p.92-101, 2014.

LUSTGARTEN, M.; REDDING, W.R.; LABENS, R. et al. Elastographic evaluation of naturally occuring tendon and ligament injuries of the equine distal limb. Vet. Radiol. Ultrasound, v.56, p.670-679, 2015.

MARXEN, S.; LACERDA-NETO, J.C.; CANOLA, J.C. et al. Intralesional polysulphated glycosaminoglycansubs as treatment of equine collagenase induced tendinitis: clinical, ultrasonographic and histopathologic evaluation. Arq. Bras. Med. Vet. Zootec., v.56, p.701-708, 2004.

MILES, C.A. Ultrasonic properties of tendon: Velocity, attenuation, and backscattering in equine digital flexor tendons. J. Acoust. Soc. Am., v.99, p.3225-3232, 1996.

NIGHTINGALE K. Acoustic Radiation Force Impulse (ARFI) imaging: a review. Curr. Med. Imaging Rev., v.7, p.328-339, 2011.

RUAN, Z.; ZHAO, B.; QI, H. et al. Elasticity of healthy Achilles tendon decreases with the increase of age as determined by acoustic radiation force impulse imaging. Int. J. Clin. Exp. Med., v.8, p.1043-1050, 2015.

RUMIAN, A.P.; WALLACE, A.L.; BIRCH, H.L. Tendons and ligaments are anatomically distinct but overlap in molecular and morphological features-a comparative study in an ovine model. J. Orthop. Res., v.25, p.458-464, 2007.
TAKAHASHI, T.; MUKAI, K.; OHMURA, H. et al. In vivo measurements of flexor tendon and suspensory ligament forces during trotting using the thoroughbred forelimb model. J. Equine Sci., v.25, p.15-22, 2014.

TAMURA, N.; NUKADA, T.; KATO, T. et al. The use of sonoelastography to assess the recovery of stiffness after equine superficial digital flexor tendon injuries: A preliminary prospective longitudinal study of the healing process. Equine Vet. J., v.49, p.590-595, 2017.

TANG, L.; XU, H.X.; BO, X.W. et al. A novel two-dimensional quantitative shear wave elastography for differentiating malignant from benign breast lesions. Int. J. Clin. Exp. Med., v.8, p.10920-10928, 2015.

VAN SCHIE, H.T.; BAKKER, E.M.; JONKER, A.M.; VAN WEEREN, P.R. Ultrasonographic tissue characterization of equine superficial digital flexor tendons by means of gray level statistics. Am. J. Vet. Res., v.61, p.210-219, 2000.

VAN SCHIE, H.T.M.; DOCKING, S.I.; DAFFY, J. et al. Ultrasound tissue characterisation, an innovative technique for injury-prevention and monitoring of tendinopathy. Br. J. Sports Med., v.47, p.14, 2013.

WAKKER, J.; KRATZER, W.; GRAETER, T.; SCHMIDBERGER, J. Elasticity standard values of the Achilles tendon assessed with acoustic radiation force impulse elastography on healthy volunteers: a cross section study. $B M C$ Musculoskelet. Disord., v.19, p.139, 2018.

WHITCOMB, M.B. Ultrasound in equine practice - where we've been, where we are now, and where we need to go. Am. Assoc. Equine Pract. Proc., v.60, p.141-160, 2014. 